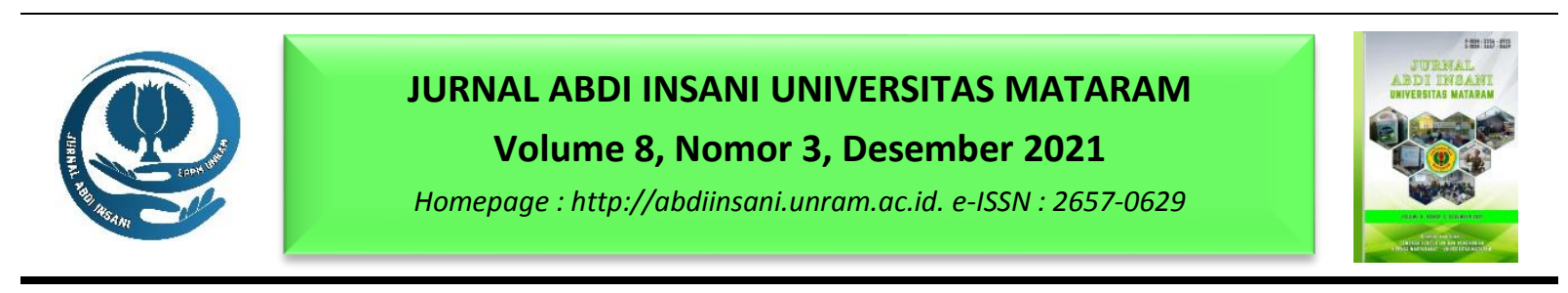

\title{
PEMANFAATAN TEKNOLOGI TOUCHLESS HAND GESTURE UNTUK MENDUKUNG PELAKSANAAN PROTOKOL KESEHATAN COVID-19 DI SD NEGERI 1 TERONG TAWAH
}

\section{Utilization Of Touchless Hand Gesture Technology To Support The Implementation of The Covid-19 Health Protocol In Sd Negeri 1 Terong Tawah}

\author{
Ario Yudo Husodo*, Arik Aranta, Fitri Bimantoro, Gibran Satya Nugraha, Noor \\ Alamsyah, Haidar Rahman
}

Program studi Teknik Informatika Universitas Mataram

Jl. Majpahit Nomor 62 Kota Mataram

*Alamat korespondensi : ario@unram.ac.id

(Tanggal Submission: 21 September 2021, Tanggal Accepted : 28 Desember 2021)

\begin{abstract}
Kata Kunci Abstrak :
:

Protokol Salah satu aspek penting di dalam protokol kesehatan Covid-19 ketika kegiatan Kesehatan, belajar mengajar berlangsung adalah mencegah disentuhnya suatu objek Sistem pembelajaran oleh peserta didik ataupun guru. Salah satu contohnya adalah Cerdas, mencegah disentuhnya suatu spidol papan tulis, penghapus papan tulis, ataupun Gerakan media pembelajaran elektronik yang mungkin seperti komputer/laptop. SD Tangan, Negeri 01 Terong Tawah merupakan sebuah Sekolah Dasar yang memiliki Touchless, akreditasi A dan berlokasi di daerah Kabupaten Lombok Barat. Seiring dengan Pembelajaran berkembangnya konsep belajar dari rumah pada masa Pandemi Covid-19, SDN Interaktif 01 Terong Tawah belum menerapkan pembelajaran berbasis e-learning, dikarenakan keterbatasan sumber daya. Salah satu peluang alternatif yang dapat diterapkan agar proses pembelajaran dapat terus berlangsung adalah dengan melaksanakan pembelajaran tatap muka dengan menerapkan protokol kesehatan Covid-19 yang tertib. Pada pengabdian ini, diperkenalkan suatu teknologi tepat guna yang memungkinkan sekumpulan peserta didik dan guru untuk berinteraksi secara interaktif, tatap muka, tanpa perlu menyentuh suatu peralatan pembelajaran apa pun secara bergantian. Tujuan utama pengabdian ini adalah untuk memberikan pemahaman terkait konsep pembelajaran interaktif dengan meminimalisir kontak terhadap suatu objek pembelajaran dengan memanfaatkan teknologi sensor kamera inframerah cerdas. Pada pengabdian ini, mitra dilatih tentang cara menggunakan suatu sensor cerdas yang memungkinkan guru dan murid untuk berinteraksi menuliskan sesuatu ataupun menggambar sesuatu tanpa perlu menyentuh apa pun. Sistem yang diperkenalkan pada pengabdian ini merupakan suatu sistem berbasis sensor kamera inframerah yang dilengkapi dengan algoritma cerdas tertentu sehingga memungkinkan sistem untuk mengenali gerakan tangan / gesture seseorang tanpa perlu menyentuh sensor (touchless) lalu menerjemahkan gerakan
\end{abstract}


tersebut untuk ditampilkan di suatu layar sebagai suatu tulisan/gambar. Dengan menggunakan teknologi ini, penerapan protokol kesehatan pada proses pembelajaran secara tatap muka dapat lebih terjaga.

Panduan sitasi / Citation guidance (APPA $7^{\text {th }}$ edition) :

Husodo, A. Y., Aranta, A., Bimantoro, F., Nugraha, G. S., Alamsyah, N., \& Rahman, H. (2021). Pemanfaatan Teknologi Touchless Hand Gesture Untuk Mendukung Pelaksanaan Protokol Kesehatan Covid-19 Di Sd Negeri 1 Terong Tawah. Abdi Insani, 8 (3), 377385. http://doi.org/10.29303/abdiinsani.v8i3.423

\section{PENDAHULUAN}

Di era pandemi Covid-19 seperti saat ini, pelaksanaan kegiatan belajar mengajar menjadi sulit untuk dilaksanakan secara efektif. Umumnya, alternatif yang dapat digunakan untuk pelaksanaan kegiatan belajar mengajar adalah menggunakan media pembelajaran secara daring (online). Sayangnya, meskipun pendekatan ini dirasa aman, pelaksanaan kegiatan pembelajaran secara online memiliki keterbatasan tersendiri. Kurangnya interaksi langsung antara peserta didik dan tenaga pengajar merupakan salah satu batasan yang dimiliki sistem pembelajaran online sehingga memungkinkan penangkapan materi pembelajaran menjadi kurang efektif. Seperti yang dipaparkan oleh (Dwiyansaputra et al., 2021), dunia Pendidikan termasuk sebagai salah satu sektor yang terdampak Covid-19.

Di satu sisi, pelaksanaan sistem pembelajaran secara tatap muka langsung (offline) dirasa berisiko apabila protokol kesehatan tidak dijaga ketat di antara tenaga pengajar dan para peserta didik. Di lain sisi, terdapat dorongan yang begitu besar bagi para peserta didik dan tenaga pengajar untuk dapat menyelenggarakan kegiatan belajar mengajar dengan metode tatap muka langsung untuk menyampaikan materi-materi khusus yang dinilai tidak dapat diterapkan secara efektif melalui pembelajaran online. Salah satu contoh penerapan sistem pembelajaran yang dinilai perlu dilakukan secara tatap muka langsung adalah pembelajaran bagi anak usia Sekolah Dasar. Peserta didik usia Sekolah Dasar, secara psikologi sangat membutuhkan interaksi langsung dengan teman sebaya dan guru pengajar. Saat ini, pembelajaran berbasis online telah memiliki beragam bentuk (Zaenuri \& Prastowo (2021); Switrayni et al., (2021)). Akan tetapi, apabila pembelajaran dilaksanakan secara online, maka kecenderungan yang dihasilkan adalah rasa bosan (Saputra, 2017), kebingungan menggunakan teknologi, dan bahkan mungkin saja teralihkan untuk menggunakan teknologi pembelajaran digital untuk bermain game. Dengan kata lain, penggunaan media pembelajaran online memberikan tantangan tersendiri untuk para peserta didik ataupun pengajar (Widodo et al., 2020).

Berdasarkan analisis di atas, terlihat bahwa diperlukan suatu solusi yang efektif dan tepat guna agar pelaksanaan sistem pembelajaran secara tatap muka dapat dilaksanakan, terutama bagi anak usia Sekolah Dasar. Pada pengabdian ini, dirancang suatu sistem pembelajaran yang memungkinkan guru dan peserta didik usia Sekolah Dasar untuk melaksanakan kegiatan pembelajaran dengan metode tatap muka langsung, interaktif, tetapi tetap dapat menjaga protokol kesehatan dengan baik. Dari sekian banyak kemungkinan protokol kesehatan yang mungkin dilanggar oleh anak usia Sekolah Dasar, aspek yang menjadi fokus kegiatan pengabdian ini adalah aspek tersentuhnya suatu objek pembelajaran oleh sekumpulan peserta didik / tenaga pengajar sehingga memungkinkan objek tersebut sebagai media transmisi virus. Untuk itu, di dalam pengabdian ini, dirancang suatu sistem pembelajaran interaktif yang memungkinkan peserta didik dan guru dapat melaksanakan proses pembelajaran tanpa perlu menyentuh objek pembelajaran. 
Di dalam pengabdian ini, sistem yang dirancang merupakan sistem cerdas berbasis teknologi kamera inframerah yang dilengkapi dengan algoritma tertentu sehingga memungkinkan sensor kamera tersebut untuk mengenali gerakan tangan seseorang. Dengan mengenali gerakan tangan tersebut, sistem kemudian menerjemahkannya menjadi suatu huruf, ataupun gambar tertentu. Di dalam pengabdian ini, fokus utama kegiatan diarahkan pada kegiatan edukasi dan pelatihan kepada para guru dan siswa Sekolah Dasar agar dapat menerapkan sistem tersebut guna menjaga protokol kesehatan apabila pihak sekolah merasa perlu melaksanakan kegiatan belajar mengajar.

Dari beragam alternatif Sekolah Dasar untuk melaksanakan pengabdian, pada pengabdian ini SD Negeri 01 Terong Tawah dipilih sebagai lokasi pelaksanaan pengabdian karena sekolah ini dinilai cocok sebagai tempat pelaksanaan. SD Negeri 01 Terong merupakan sebuah Sekolah Dasar yang memiliki akreditasi A yang terletak di Kecamatan Labuapi , Provinsi Nusa Tenggara Barat dan telah menerapkan kurikulum K-13, Sekolah Dasar tersebut menurut data yang tercatat pada data Kemendikbud memiliki 10 Guru, 136 siswa laki-laki, 102 siswa perempuan 6 ruang kelas, dan 1 perpustakaan (Kemendikbud RI, 2021). Seiring dengan penerapan belajar dari rumah pada masa Pandemi Covid-19, SDN 01 Terong Tawah belum menerapkan pembelajaran berbasis e-learning, dikarenakan keterbatasan sumber daya. Salah satu peluang alternatif yang dapat diterapkan agar proses pembelajaran dapat terus berlangsung adalah dengan menyelenggarakan pembelajaran tatap muka dengan menerapkan protokol kesehatan Covid-19 yang tertib.

Penerapan protokol kesehatan tergolong sebagai hal penting di momen pandemi Covid-19 seperti sekarang. Bagi kalangan dewasa saja, penerapan protokol Kesehatan terkadang lalai untuk dilakukan. Penerapan protokol Kesehatan untuk anak usia Sekolah Dasar, tentunya memiliki tantangan tersendiri. Dari seluruh protokol Kesehatan yang perlu dijaga di antara anak usia Sekolah Dasar, salah satu aspek esensial di dalam protokol kesehatan ketika kegiatan belajar mengajar berlangsung adalah mencegah disentuhnya suatu objek pembelajaran oleh sekumpulan peserta didik ataupun guru. Salah satu contohnya adalah mencegah disentuhnya suatu spidol papan tulis, penghapus papan tulis, ataupun media pembelajaran elektronik yang mungkin seperti komputer/laptop.

Pada pengabdian ini, akan diperkenalkan suatu teknologi tepat guna yang memungkinkan sekumpulan peserta didik dan guru untuk berinteraksi secara interaktif, tatap muka, tanpa perlu menyentuh suatu peralatan pembelajaran apa pun secara bergantian. Pada pengabdian ini, mitra akan dilatih tentang cara menggunakan suatu sensor cerdas yang memungkinkan guru dan murid untuk berinteraksi menuliskan sesuatu ataupun menggambar sesuatu tanpa perlu menyentuh apa pun. Sistem yang diperkenalkan pada pengabdian ini merupakan suatu sistem berbasis sensor kamera inframerah yang dilengkapi dengan algoritma cerdas tertentu sehingga memungkinkan sistem untuk mengenali gerakan tangan / gesture seseorang tanpa perlu menyentuh sensor (touchless) lalu menerjemahkan gerakan tersebut untuk ditampilkan di suatu layar sebagai suatu tulisan/gambar. Dengan menggunakan teknologi ini, penerapan protokol kesehatan pada proses pembelajaran secara tatap muka dapat lebih terjaga.

Tujuan kegiatan pengabdian pemanfaatan teknologi touchless hand gesture ini kepada guru dan staf akademik SDN 1 Terong Tawah adalah untuk memberikan pemahaman terkait konsep pembelajaran interaktif dengan meminimalisir kontak terhadap suatu objek pembelajaran dengan memanfaatkan teknologi sensor kamera inframerah cerdas. Dengan dilakukannya pengabdian ini, diharapkan penerapan protokol Kesehatan pada proses pembelajaran secara tatap muka di SDN 1 Terong Tawah dapat lebih terjaga. 
Manfaat dari kegiatan pelatihan pemanfaatan teknologi touchless hand gesture sebagai teknologi penunjang kegiatan pembelajaran tatap muka di SDN 1 Terong Tawah adalah sebagai berikut:

1. Bagi siswa SD Negeri 1 Terong Tawah, dapat memperoleh alternatif pendekatan pembelajaran tatap muka yang lebih interaktif dan aman secara protokol Kesehatan karena memungkinkan siswa SD dapat berinteraksi belajar tatap muka tanpa perlu melakukan kontak fisik terhadap suatu objek pembelajaran.

2. Bagi guru SD Negeri 1 Terong Tawah dapat meningkatkan keleluasaan guru di dalam menerangkan suatu objek pembelajaran tanpa perlu melakukan kontak fisik terhadap suatu objek pembelajaran sehingga risiko penularan Covid 19 di SDN 1 Terong Tawah dapat ditekan.

\section{METODE KEGIATAN}

Kegiatan pelatihan ini dilaksanakan secara bertahap melalui beberapa prosedur. Prosedur pengabdian diawali dengan survei tempat pengabdian, pengurusan izin kegiatan, penyusunan materi pelatihan, dan penentuan jadwal terkait kesediaan waktu para pengajar (guru) agar dapat mengikuti pelatihan. Berikutnya, secara teknis pelaksanaan kegiatan ini dilaksanakan dengan format pelatihan penggunaan sensor cerdas touchless hand gesture untuk mendukung pelaksanaan protokol kesehatan dalam kegiatan belajar mengajar secara offline. Secara umum, Gambar 1 menunjukkan diagram alir yang memaparkan langkah-langkah pelaksanaan kegiatan pengabdian.

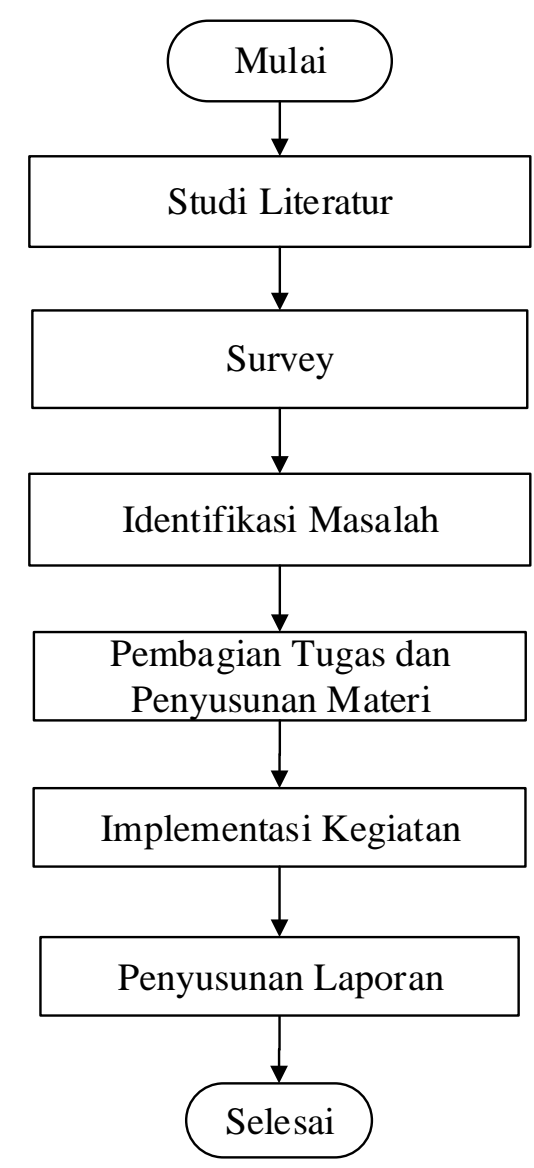

Gambar 1. Diagram Alir Pelaksanaan Kegiatan Pengabdian 
Adapun penjelasan rangkaian prosedur pada Gambar 1 adalah sebagai berikut:

a. Studi Literatur

Pada tahapan ini, dilakukan telaah awal terhadap berbagai sumber mengenai kebutuhan mitra terhadap sistem dan teknologi pembelajaran yang bermanfaat bagi pihak mitra.

b. Survei

Tim pengabdian melakukan survei ke pihak mitra yang menjadi lokasi penyelenggaraan kegiatan pengabdian masyarakat.

c. Identifikasi Masalah

Tim pengabdian melakukan analisis dan wawancara terhadap pihak perwakilan mitra untuk mengetahui lebih dalam perihal permasalahan yang dihadapi.

d. Pembagian Tugas

Untuk dapat menyelenggarakan kegiatan ini, tim terlebih dahulu berkoordinasi untuk merancang waktu pelaksanaan kegiatan, pembagian tugas tim, dan peran masing-masing anggota.

e. Implementasi Kegiatan

Implementasi kegiatan pengabdian terdiri atas 2 bagian utama. Pertama, adalah perancangan sistem cerdas yang akan diperkenalkan kepada pihak mitra, kedua adalah proses pelatihan penggunaan sistem cerdas ke pihak mitra.

f. Penyusunan Laporan

Pada tahap ini, dilakukan penyusunan laporan akhir berupa dokumentasi kegiatan pengabdian yang telah dilakukan.

Evaluasi kegiatan pelatihan dilaksanakan pada saat penyelenggaraan kegiatan dengan menganalisis partisipasi dan antusiasme peserta dalam mengikuti pelatihan, pemahaman materi, serta mempraktikkan proses penggunaan sistem cerdas. Di samping itu, komunikasi lanjutan dengan pihak mitra dapat dilakukan melalui WA atau telepon guna berdiskusi tentang kendala-kendala yang dihadapi terkait beragam hal yang berhubungan dengan kegiatan pengabdian.

Pemilihan SD Negeri 1 Terong Tawah sebagai lokasi pengabdian dikarenakan kurang efektifnya pelaksanaan pembelajaran di masa pandemi dikarenakan sekolah tidak memiliki fasilitas E-learning dan terdapat masalah lain yakni tidak semua peserta didik memiliki laptop dan smartphone, sehingga solusi yang kami berikan adalah melakukan pelatihan bagaimana menggunakan sensor kamera inframerah cerdas yang memungkinkan peserta didik ataupun guru dapat berinteraksi secara offline dengan memimalisasi tersentuhnya suatu objek pembelajaran secara bersama-sama.

Adapun peralatan yang diperlukan dalam pengabdian dalam bentuk pelatihan ini berupa:

1 Perangkat laptop/komputer/smartphone;

2 Koneksi Internet

3 LCD Proyektor

4 Materi Pelatihan

5 Ruang Kelas

6 Sensor kamera inframerah

\section{HASIL DAN PEMBAHASAN}

Pada pengabdian ini, diperkenalkan suatu sistem dan teknologi pembelajaran yang memungkinkan guru dan siswa Sekolah Dasar untuk berinteraksi secara natural dalam proses pembelajaran tanpa perlu menyentuh suatu objek pembelajaran secara bergantian. Adapun teknologi yang dimaksud adalah teknologi sensor kamera inframerah yang memungkinkan dideteksinya posisi 
tangan seseorang relatif terhadap posisi kamera. Dengan menggunakan algoritma cerdas khusus yang dikembangkan oleh tim, sistem tersebut akan mampu mengenali gerakan tangan (gesture) seseorang, kemudian menerjemahkan gesture tersebut sebagai suatu aksi tertentu.

Aktivitas utama di dalam pengabdian ini adalah menyampaikan materi yang berkaitan dengan pentingnya penggunaan sensor inframerah cerdas untuk mendukung kegiatan belajar mengajar offline. Materi disampaikan dengan metode utama berupa ceramah disertai dengan demonstrasi cara penggunaan sensor. Materi yang disampaikan pada saat pelatihan secara umum terdiri atas beberapa pembahasan, yaitu pertama pembahasan mengenai pentingnya penggunaan sensor kamera inframerah cerdas untuk mendukung kegiatan belajar mengajar offline, terutama untuk mendukung kegiatan pembelajaran interaktif tanpa perlu menyentuh suatu objek pembelajar. Selanjutnya, pembahasan diarahkan pada demo penggunaan sensor kamera cerdas yang telah dipaparkan pada pembahasan pertama.

Sasaran kegiatan pelatihan ini adalah para guru SD Negeri 01 Terong Tawah sehingga para peserta dapat memanfaatkan teknologi yang dijabarkan secara optimal untuk mempermudah proses pembelajaran dengan menjaga protokol kesehatan. Kegiatan ini adalah salah satu wujud kepedulian Universitas Mataram, khususnya Program Studi Teknik Informatika - Fakultas Teknik terhadap SD Negeri 01 Terong Tawah di Lombok Barat dalam pemanfaatan teknologi informasi untuk hal-hal yang berkaitan dengan persiapan sekolah dan siswa dalam menjalani proses pembelajaran di masa pandemi Covid-19. Selain itu, kegiatan pelatihan ini merupakan sarana promosi lembaga perguruan tinggi, khususnya Prodi Teknik Informatika kepada Masyarakat. Dengan kegiatan ini, diharapkan masyarakat dapat lebih tertarik menguliahkan anak-anak mereka di bidang Teknik Informatika Universitas Mataram.
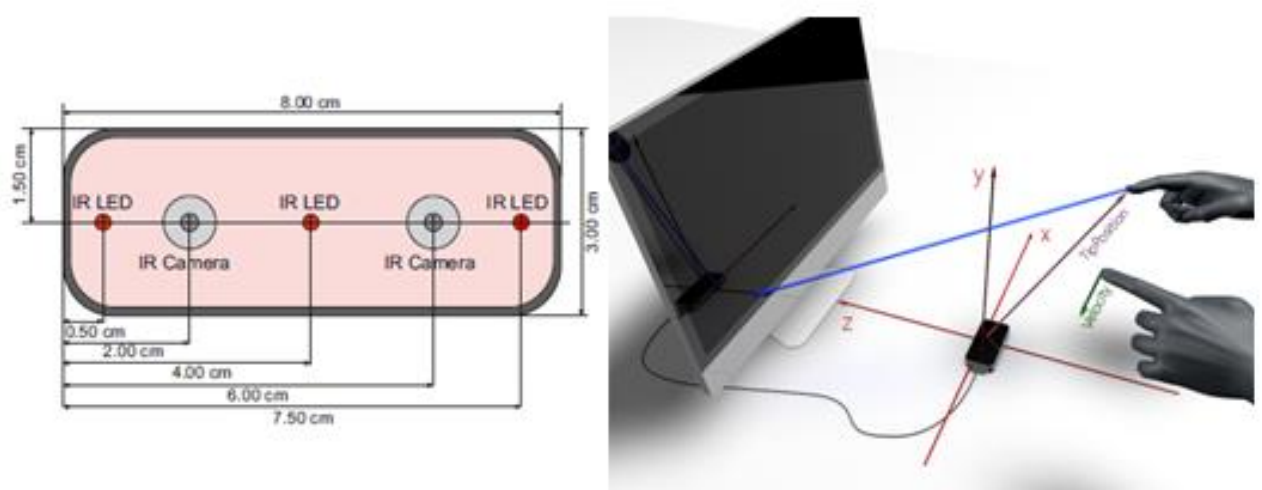

Gambar 2. Contoh Penerapan Sensor Touchless Hand Gesture (Weichert et al., 2013)

Gambar 2 dan Gambar 3 menunjukkan ilustrasi sederhana rancangan sistem yang akan diperkenalkan kepada SD Negeri 01 Terong Tawah. Berdasarkan kedua gambar tersebut, dapat dilihat bahwa seseorang mampu mengendalikan interaksi di suatu peralatan digital tanpa perlu menyentuh sensor yang ada. Di masa pandemi Covid-19 seperti saat ini, dengan meminimalisasi sentuhan terhadap objek publik, tentunya hal ini dapat membantu menekan proses penyebaran virus Covid-19. Jika diperhatikan dengan saksama, penerapan teknologi pada Gambar 2 dan Gambar 3 dapat diimplementasikan dalam beragam kegiatan belajar mengajar, seperti matematika, IPA, kesenian, ataupun proses pembelajaran lain yang membutuhkan ilustrasi. Dari rancangan Gambar 2 dan Gambar 3 ini, terlihat bahwa sistem yang ingin diperkenalkan merupakan sistem yang bermanfaat. 


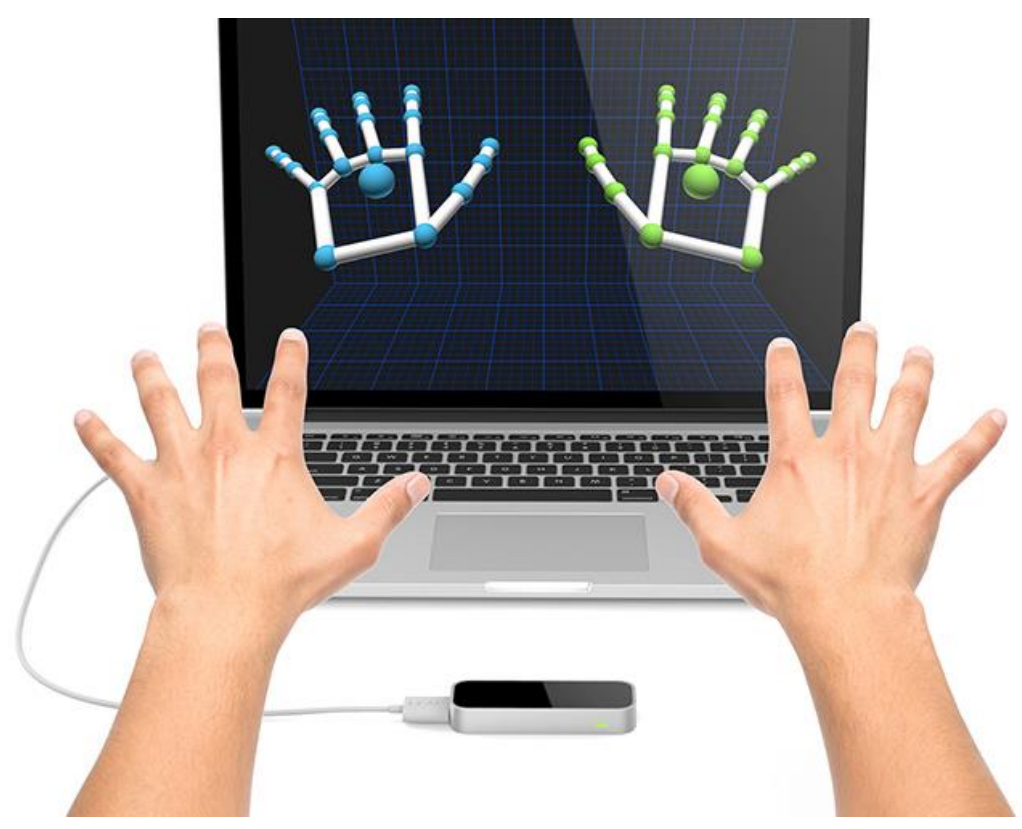

Gambar 3. Contoh Hasil Interpretasi Sensor Touchless Hand Gesture (Ultrahaptics Ltd, 2019)

Gambar 4 - Gambar 7 menunjukkan bagaimana proses sosialisasi dilakukan. Pada Gambar 4, terlihat kondisi peserta ketika kegiatan pengabdian dibuka. Pada Gambar 5, terlihat dinamika penyampaian materi pengabdian. Pada Gambar 6, terlihat suasana penyelenggaraan sesi tanya jawab dan diskusi kegiatan pengabdian. Pada Gambar 7, terlihat antusiasme peserta di akhir kegiatan pengabdian. Berdasarkan gambar-gambar tersebut, terlihat bahwa peserta pengabdian antusias dan tertarik dengan materi yang dilakukan. Setelah materi pengabdian selesai dilakukan, selanjutnya peserta diminta untuk mengisi kuesioner berupa Google Form untuk mengetahui tingkat penerimaan peserta terhadap materi pengabdian. Adapun hasil pengisian kuesioner dapat dilihat pada Gambar 8 dan Gambar 9. Gambar 8 menunjukkan diagram batang opini peserta terhadap kegiatan pengabdian. Berdasarkan Gambar 8, terlihat bahwa $100 \%$ peserta menilai kegiatan ini bermanfaat. Pada Gambar 9 , ditampilkan diagram lingkaran untuk mengukur animo peserta apabila kegiatan pengabdian serupa diselenggarakan kembali. Berdasarkan Gambar 9, terlihat bahwa 100\% peserta tertarik untuk mengikuti kegiatan serupa apabila diselenggarakan di masa yang akan datang. Berdasarkan Gambar 8 dan Gambar 9, dapat dilihat bahwa seluruh peserta pelatihan merasa bahwa pengabdian yang dilakukan tergolong bermanfaat dan tertarik untuk mengikuti kegiatan sejenis apabila dilakukan kembali.

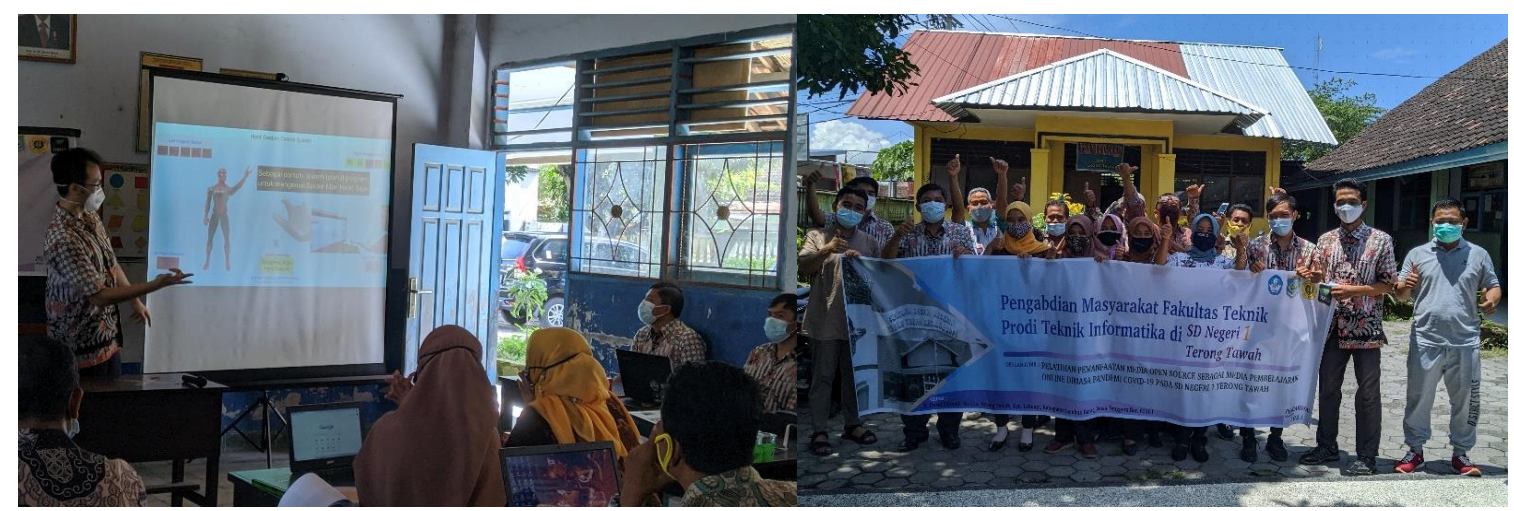

Gambar 4. Pelaksanaan Kegiatan Pengabdian 


\section{Apakah menurut anda apakah pelatihan ini bermanfaat?}

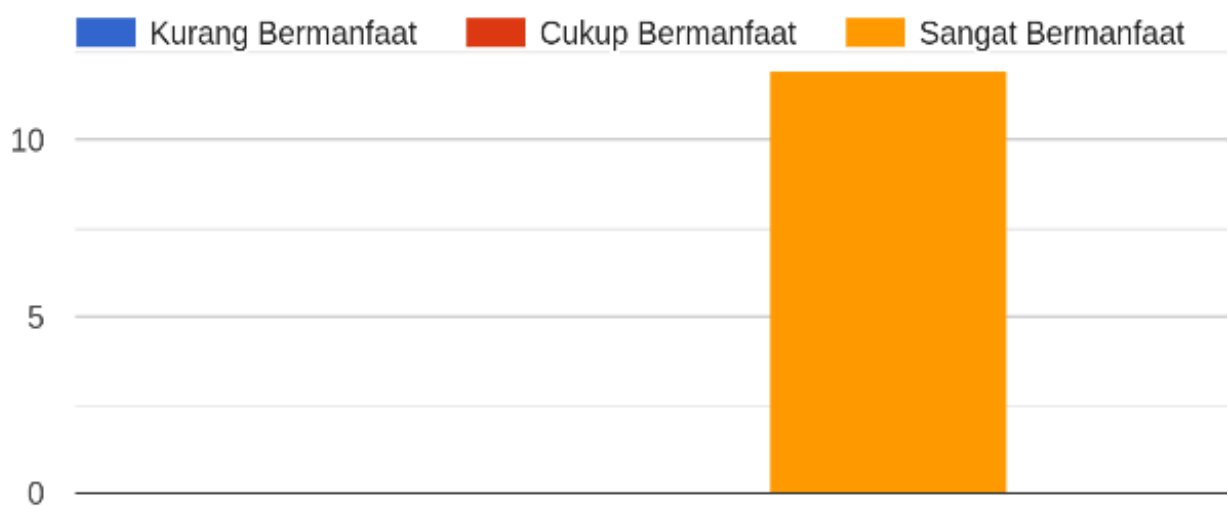

Gambar 5. Grafik Opini Peserta Terkait Kebermanfaatan Kegiatan

Apabila dilaksanakan kembali apakah anda tertarik untuk mengikuti?

12 responses

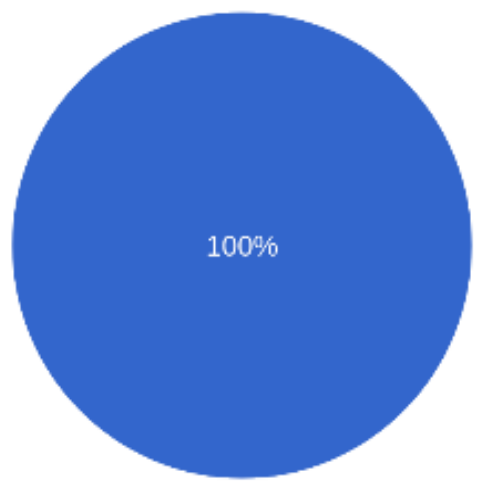

Ya (Bersedia)

Tidak (Belum tertarik)

Gambar 6. Grafik Minat Peserta untuk Mengikuti Pelatihan Lanjutan

\section{KESIMPULAN DAN SARAN}

\section{Kesimpulan}

Adapun poin kesimpulan yang dapat diambil melalui kegiatan pengabdian kepada masyarakat ini adalah sebagaimana berikut:

1. Dengan dilakukannya kegiatan ini, membuat Guru SD Negeri 1 Terong Tawah yang mengikuti pelatihan, memahami pentingnya pemanfaatan teknologi digital di dalam menunjang kegiatan pembelajaran tatap muka yang menjaga protokol kesehatan di masa pandemi Covid-19 dengan baik.

Saran

Beberapa saran yang dapat diberikan berdasarkan kegiatan pengabdian ini antara lain : 
1. Diperlukan program pengabdian masyarakat pada SD Negeri 1 Terong Tawah dengan model bertahap dan berkesinambungan agar efektivitas pengabdian dapat memberikan dampak jangka panjang bagi pihak mitra pengabdian.

2. Diperlukan pengabdian serupa dengan topik-topik pelengkap terkait sistem pembelajaran di masa pandemi, seperti penggunaan E-Learning berbasis web Moodle yang dapat membuat proses belajar selama pandemi dapat lebih menarik dan interaktif.

\section{UCAPAN TERIMA KASIH}

Ucapan terima kasih disampaikan kepada Universitas Mataram dan Lembaga Penelitian dan Pengabdian Kepada Masyarakat Universitas Mataram, atas bantuan dana yang diberikan melalui program: Kontrak Pengabdian Sumber Dana DIPA BLU Skema Kemitraan Universitas Mataram Tahun Anggaran 2021 Nomor 1896/UN18.L1/PP/2021. Serta kepada Kepala Sekolah SD Negeri 1 Terong Tawah, beserta guru dan staf yang telah memberikan izin dan mengikuti kegiatan pelatihan yang diadakan.

\section{DAFTAR PUSTAKA}

Dwiyansaputra, R., Wijaya, I. G. P. S., Bimantoro, F., Nugraha, G. S., \& Aranta, A. (2021). Pelatihan Penggunaan Aplikasi Zoom Untuk Proses Pembelajaran Daring Pada Masa Pandemi Covid-19 Di SD Negeri 10 Cakranegara. Jurnal Begawe Teknologi Informasi (JBegaTI), 2(1), 62-69. https://doi.org/https://doi.org/10.29303/jbegati.v2i1.337

Kemendikbud RI. (2021). Sekolah Kita. https://sekolah.data.kemdikbud.go.id/

Saputra, S. Y. (2017). Permainan Tradisional VS Permainan Modern Dalam Penanaman Nilai Karakter di Sekolah Dasar. ELSE (Elementary School Education Journal): Jurnal Pendidikan Dan Pembelajaran Sekolah Dasar, 1(1), 85-94. https://doi.org/https://doi.org/10.30651/else.v1i1.873

Switrayni, N. W., Wardhana, I. G. A. W., Irwansyah;, Aini, Q., \& Salwa. (2021). Webinar Pengenalan Google Classroom Dan Google Form Sebagai Media Dan Alat Evaluasi Pembelajaran Daring Pada Masa Pandemi Covid-19. Abdi Insani, 8(1), 18-24. https://doi.org/Https://Doi.Org/10.29303/Abdiinsani.V8i1.366

Ultrahaptics Ltd. (2019). Leap Motion. https://www.leapmotion.com/

Weichert, F., Bachmann, D., Rudak, B., \& Fisseler, D. (2013). Analysis of the Accuracy and Robustness of the Leap Motion Controller. Sensors, 13(5), 6380-6393. https://doi.org/https://doi.org/10.3390/s130506380

Widodo, A., Ermiana, I., \& Erfan, M. (2020). Emergency Online Learning: How Are Students' Perceptions? Proceedings of the 4th Sriwijaya University Learning and Education International Conference (SULE-IC 2020). www.atlantis-press.com/proceedings/sule-ic-20/125950288

Zaenuri, \& Prastowo, A. (2021). Peran Guru dalam Perencanaan Pembelajaran Berbasis Aplikasi Zoom Meeting di Sekolah Dasar. Edukatif: Jurnal IImu Pendidikan, 3(4), 1734-1744. https://doi.org/https://doi.org/https://doi.org/10.31004/edukatif.v3i4.654 